\title{
Structural and Biochemical Studies of Dihydrofolate Reductase from Streptococcus pyogenes as a Target for Antifolate Antibiotics
}

\author{
Behnoush Hajian1, Jolanta Krucinska1, Michael Martins², Narendran G-Dayanan1, \\ Kishore Viswanathan', Sara Tavakoli², Dennis Wright ${ }^{1}$ \\ 1'Department of Pharmaceutical Sciences, University of Connecticut, Storrs, CT 06269 \\ ${ }^{2}$ Department of Cellular and Molecular Biology, University of Connecticut, Storrs, CT \\ 06269
}

Corresponding author: Dennis Wright, dennis.wright@uconn.edu 


\begin{abstract}
Streptococcus pyogenes, a beta-hemolytic bacterium, causes a wide spectrum of infections in human including pharyngitis, tonsillitis, scarlet fever, rheumatic fever, and necrotizing fasciitis. Streptococcal infections can also exist as co-infection with methicillin resistant Staphylococcus aureus (MRSA). Trimethoprim-sulfamethoxazole (TMP-SMX) combination has been used for treatment of $S$. pyogenes and MRSA co-infection. However, resistance to TMP, an inhibitor of dihydrofolate reductase enzyme (DHFR), has challenged the efficacy of TMP-SMX combination. We explored the activity of a series of novel DHFR inhibitors against $S$. pyogenes. This study identified potent inhibitors of DHFR enzyme from $S$. pyogenes with excellent inhibitory activity against the growth of the live bacteria. We determined, for the first time, the crystal structure of $S$. pyogenes DHFR which provides structural insights into design and development of antifolate agents against this global pathogen.
\end{abstract}

Key words: Streptococcus pyogenes, folate pathway, dihydrofolate reductase, trimethoprim, MRSA, antifolates 


\section{INTRODUCTION}

Streptococcus pyogenes, or Lancefield's group A Streptococcus (GAS), is a Grampositive bacterium that causes a diverse spectrum of human infections. Streptococcal infections are usually mild such as pharyngitis (strep throat) and impetigo. But if the infection reaches deeper tissues, it can cause invasive infections such as necrotizing fasciitis (flesh eating disease) and streptococcal toxic shock syndrome. Superficial GAS infections can be followed by abnormal immune responses which may result in post-streptococcal sequelae including acute rheumatic fever and acute poststreptococcal glomerulonephritis. ${ }^{1}$ The prevalence of severe GAS infections is 18.1 million cases, with 1.78 new cases and 517000 deaths each year. The past decade has witnessed a global resurgence of streptococcal diseases such as skin and soft tissue infections and scarlet fever. ${ }^{2,3}$

Although, S. pyogenes in general remains susceptible to most classes of antibiotics, treatment of streptococcal infections is challenged by the rising tide of antimicrobial resistance (AMR). ${ }^{4-7}$ Over the past two decades, there has been an increasing rate of macrolide resistance among $S$. pyogenes isolates in Europe and worldwide. ${ }^{8-11}$ There has been also a growing rate of penicillin failure mostly due to lack of penicillin permeation into the infected tissues and co-infection of $S$. pyogenes with beta- lactamase producing bacteria such as Staphylococcus aureus. ${ }^{4}$

Trimethoprim-sulfamethoxazole combination (SXT), one of the most widely used and cheapest antibacterials in the world, is currently suggested as a valuable option for treatment of skin and soft tissue coinfections with $S$. pyogenes and methicillin-resistant $S$. aureus (MRSA), when penicillin treatment fails. ${ }^{12}$ However, the emergence of trimethoprim (TMP) resistance in $S$. pyogenes isolates have challenged the efficacy of SXT. ${ }^{13,14}$ TMP is an inhibitor of dihydrofolate reductase (DHFR), one of the key enzymes in the folate biosynthetic pathway. The folate pathway is essential in the synthesis of reduced folates, the one-carbon donors required for the production of deoxythymidine monophosphate (dTMP), purine nucleotides, methionine and histidine (Figure 1). DHFR catalyzes the reduction of DHF to THF using $\mathrm{NADPH}$ as an electron donor. Due to its pivotal role in regulating cellular levels of THF and its derivatives, DHFR has served as an attractive target for many anticancer, antibacterial, and antiprotozoal drugs. ${ }^{15,16}$

Herein, we report the activity of a series of propargyl-linked antifolates (PLAs) against $S$. pyogenes and DHFR enzyme from this pathogen (SpDHFR). Previously, we have shown that PLAs are inhibitors of TMP-susceptible and TMPresistant MRSA isolates. ${ }^{17-20}$ Screening of 
PLAs against S. pyogenes identified a group of novel PLAs with pronounced antibacterial activity. Further exploration of structure activity relationship (SAR) of this group has led to the identification of potent inhibitors of SpDHFR enzyme.

Here we report for the first-time high resolution crystal structure of SpDHFR in a ternary complex with NADPH and one of the lead PLAs which provides structural insights into the design of potent and selective inhibitors. Our data strongly support the effort to explore PLAs as promising candidate for design of novel antifolates against TMPresistant $S$. pyogenes and MRSA coinfections.

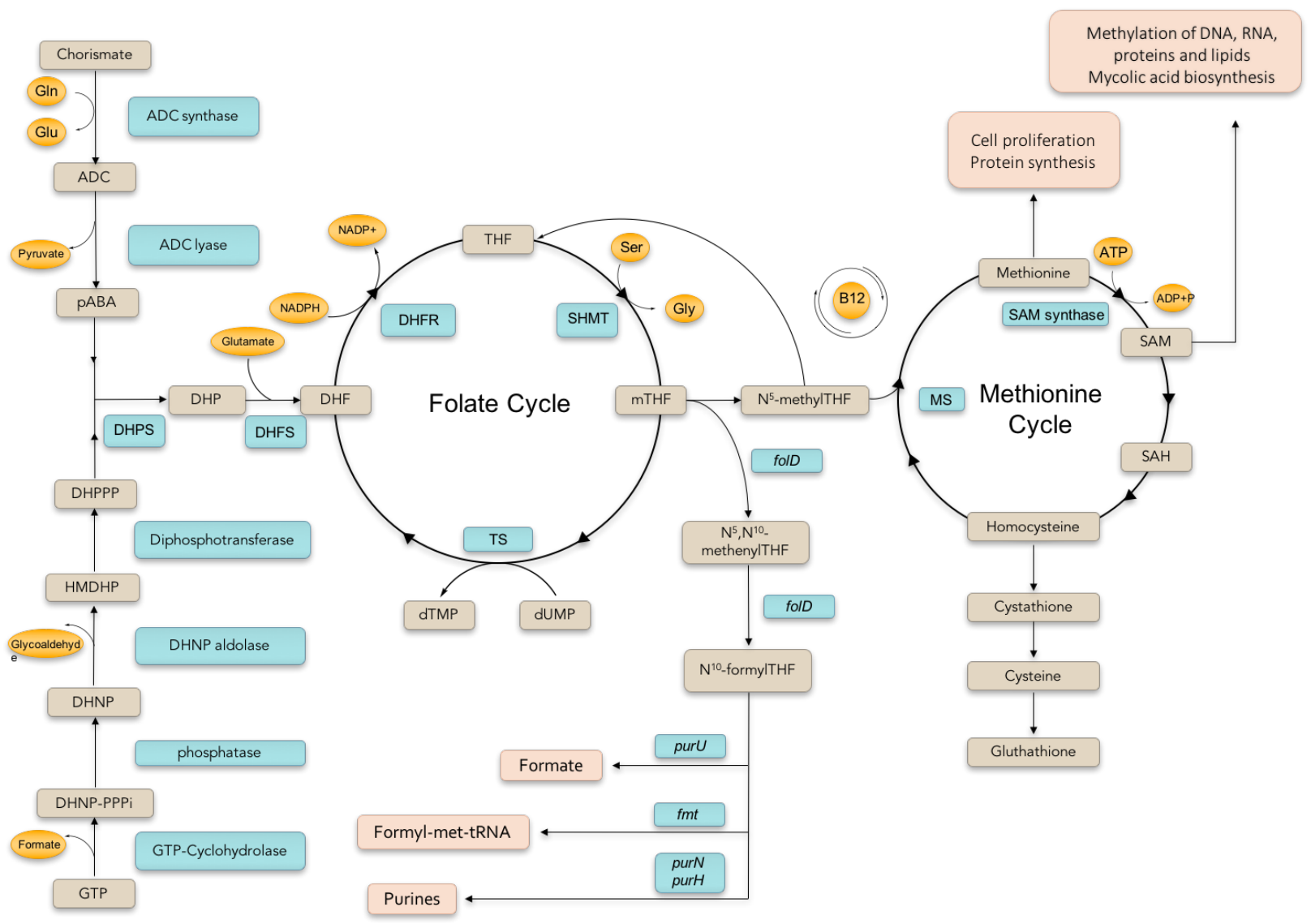

Figure 1. Bacterial folate cycle and related pathways. ADC: aminodeoxy chorismate, PABA: para-aminobenzoic acid, DHPPP: 7,8-dihydropterin pyrophosphate, HMDHP: 6-hydroxymethyl-7,8-dihydropterin, DHNP: 7,8-dihydroneopterine, DHNP-PPPi: 7,8-dihydroneopterine triphosphate, DHP: 7,8-dihydropteroate, DHF: 7,8-dihydrofolate, THF: 5,6,7,8-tetrahydrofolate, DHFR: dihydrofolate reductase, SHMT: serine hydroxymethyltransferase, mTHF: $\mathrm{N}^{5}, \mathrm{~N}^{10}$-methyleneTHF, 5-mTHF: $\mathrm{N}^{5}$-methylTHF, TS: thymidylate synthase, MS: methionine synthase, SAM: S-adenosyl methionine, SAH: S-adenosyl homocysteine

RESULTS

Antimicrobial activity of PLAs against

S. pyogenes. Using broth micro dilution method, a series of PLAs were tested for their inhibitory activity against the growth of S. pyogenes ATCC 19615 
(Rosenbach), a quality control strain used in a variety of susceptibility assays. PLASs scaffold includes a 2,4diaminopyrimidine ring (ring $A$ ) linked to an aryl or heteroaryl system (ring $B$ and C) through a propargyl bridge. Based on the variations in the $\mathrm{B}$ - and $\mathrm{C}$-rings, the tested PLAs were categorized into six general groups (Table 1 and Table S1). With only one exception (compound 34), all the tested compounds exhibited very promising antimicrobial activity against S. pyogenes with MIC values below 1 $\mu \mathrm{g} / \mathrm{ml}$.

Inhibition of $S$. pyogenes DHFR enzyme by PLAs. To test whether the inhibitory activity of PLAs against $S$. pyogenes cells is mediated through the inhibition of DHFR enzyme, we evaluated the inhibitory effect of the compounds against the purified enzyme. The half maximal inhibitory concentrations ( $I C_{50}$ values) are shown in Table 1. Although the potency of the compounds varies, in general there is a correlation between the enzyme and cell growth inhibition. SAR analysis of each group of the tested compounds elucidated key structural features that affect the potency of PLAs against SpDHFR.

Group one is characterized by PLA$\mathrm{COOH}$ compounds which feature a carboxylic acid substitution on the Cring. The $I_{50}$ values observed in this category varies between 50 to $250 \mathrm{nM}$. Within this group, the presence of propargylic methyl correlates with a decrease in the potency of the compounds. As seen with compounds 1 and 7 , the absence of propargylic methyl leads to improved inhibitory activity against SpDHFR (IC 50 values of 73 and 57 $\mathrm{nM}$, respectively). In addition, moving the carboxylate from the para (in compound 7) to the ortho position (in compound 6) compromised the inhibitory effect by almost four-folds $\left(I_{50}\right.$ values of 57 and $200 \mathrm{nM}$, respectively). Furthermore, the stereoisomers of $S$ configuration (compounds 2 and 4) exhibit similar activity with $R$ isomers (compounds 3 and 5). The lack of apparent stereospecificity is continuously evident across all the other tested PLAs.

Compounds in group two feature a pyrimidine C-ring and a chlorine substitution at 2 ' position on the B-ring. Here, compound $\mathbf{8}$ is the most potent congener with $\mathrm{IC}_{50}$ value of $85 \mathrm{nM}$. Introduction of two methyl groups on the C-ring (compound 10) leads to a modest decrease in inhibitory affinity $\left(\mathrm{IC}_{50}\right.$ value of $193 \mathrm{nM}$ ).

Based on the same concept, group three represents fluorine atoms substitution on the B-ring. $I C_{50}$ values for this group range from 40 to $350 \mathrm{nM}$. Not surprisingly, the presence of propargylic methyl and/or methyl substitutions on the C-ring reflects the same trend as seen with chlorine atom derivatives.

Next we evaluated the effect of heterocyclic substitution on the B-ring by 
bioRxiv preprint doi: https://doi.org/10.1101/504357; this version posted December 21,2018 . The copyright holder for this preprint (which was not certified by peer review) is the author/funder. All rights reserved. No reuse allowed without permission.

introducing a dioxane and dioxalane moieties on the B-ring (Group four and five). 
Table 1. Biological activity of PLAs against $S$. pyogenes and DHFR enzymes

\begin{tabular}{|c|c|c|c|c|c|c|c|c|c|c|c|c|c|}
\hline Structures & ID & $\mathrm{R}_{1}$ & $\mathrm{R}_{2}$ & $\mathrm{R}_{3}$ & $\mathrm{R}_{4}$ & $\mathrm{R}_{5}$ & $\mathrm{X}_{1}$ & $X_{2}$ & $X_{3}$ & $\mathrm{n}$ & $\begin{array}{l}\text { SpDHFR } \\
I C_{50}(n M)\end{array}$ & $\begin{array}{r}\mathrm{MIC} \\
(\mu \mathrm{g} / \mathrm{mL})\end{array}$ & $\begin{array}{l}\text { HuDHFR } \\
I^{\prime} C_{50}(n M)\end{array}$ \\
\hline \multirow[t]{7}{*}{ Group 1} & 1 & $\mathrm{H}$ & $\mathrm{H}$ & $\mathrm{OCH}_{3}$ & $\mathrm{H}$ & $\mathrm{COOH}$ & - & - & - & - & $73 \pm 5$ & $\leq 0.039$ & $688 \pm 12$ \\
\hline & 2 & $\mathrm{~S}-\mathrm{CH}_{3}$ & $\mathrm{H}$ & $\mathrm{OCH}_{3}$ & $\mathrm{H}$ & $\mathrm{COOH}$ & - & - & - & - & $142 \pm 8$ & $\leq 0.039$ & $400 \pm 20$ \\
\hline & 3 & $\mathrm{R}-\mathrm{CH}_{3}$ & $\mathrm{H}$ & $\mathrm{OCH}_{3}$ & $\mathrm{H}$ & $\mathrm{COOH}$ & - & - & - & - & $250 \pm 8$ & $\leq 0.039$ & $502 \pm 15$ \\
\hline & 4 & $\mathrm{~S}-\mathrm{CH}_{3}$ & $\mathrm{OCH}_{3}$ & $\mathrm{H}$ & $\mathrm{H}$ & $\mathrm{COOH}$ & - & - & - & - & $226 \pm 12$ & 0.078 & $520 \pm 14$ \\
\hline & 5 & $\mathrm{R}-\mathrm{CH}_{3}$ & $\mathrm{OCH}_{3}$ & $\mathrm{H}$ & $\mathrm{H}$ & $\mathrm{COOH}$ & - & - & - & - & $185 \pm 9$ & 0.078 & $266 \pm 15$ \\
\hline & 6 & $\mathrm{H}$ & $\mathrm{OCH}_{3}$ & $\mathrm{H}$ & $\mathrm{COOH}$ & $\mathrm{H}$ & - & - & - & - & $200 \pm 16$ & 0.625 & $3547 \pm 230$ \\
\hline & 7 & $\mathrm{H}$ & $\mathrm{OCH}_{3}$ & $\mathrm{H}$ & $\mathrm{H}$ & $\mathrm{COOH}$ & - & - & - & - & $57 \pm 5$ & 0.078 & $870 \pm 22$ \\
\hline \multirow[t]{4}{*}{ Group 2} & 8 & $\mathrm{CH}_{3}$ & $\mathrm{Cl}$ & $\mathrm{H}$ & $\mathrm{H}$ & - & - & - & - & - & $85 \pm 4$ & & ND \\
\hline & 9 & $\mathrm{~S}-\mathrm{CH}_{3}$ & $\mathrm{Cl}$ & $\mathrm{CH}_{3}$ & $\mathrm{CH}_{3}$ & - & - & - & - & - & $243 \pm 12$ & $\leq 0.039$ & $210 \pm 18$ \\
\hline & 10 & $\mathrm{CH}_{3}$ & $\mathrm{Cl}$ & $\mathrm{CH}_{3}$ & $\mathrm{CH}_{3}$ & - & - & - & - & - & $193 \pm 16$ & 0.312 & ND \\
\hline & 11 & $\mathrm{R}-\mathrm{CH}_{3}$ & $\mathrm{Cl}$ & $\mathrm{CH}_{3}$ & $\mathrm{CH}_{3}$ & - & - & - & - & - & $375 \pm 21$ & 0.625 & $207 \pm 13$ \\
\hline \multirow[t]{6}{*}{ Group 3} & 12 & $\mathrm{~S}-\mathrm{CH}_{3}$ & $\mathrm{OCF}_{3}$ & $\mathrm{H}$ & $\mathrm{CH}_{3}$ & $\mathrm{CH}_{3}$ & - & - & - & - & $354 \pm 25$ & 0.312 & ND \\
\hline & 13 & $\mathrm{R}-\mathrm{CH}_{3}$ & $\mathrm{OCF}_{3}$ & $\mathrm{H}$ & $\mathrm{CH}_{3}$ & $\mathrm{CH}_{3}$ & - & - & - & - & $288 \pm 22$ & 0.156 & $167 \pm 9$ \\
\hline & 14 & $\mathrm{H}$ & $\mathrm{OCF}_{3}$ & $\mathrm{H}$ & $\mathrm{CH}_{3}$ & $\mathrm{CH}_{3}$ & - & - & - & - & $212 \pm 18$ & 0.625 & ND \\
\hline & 15 & $\mathrm{CH}_{3}$ & $\mathrm{OCF}_{3}$ & $\mathrm{H}$ & $\mathrm{CH}_{3}$ & $\mathrm{CH}_{3}$ & - & - & - & - & $157 \pm 13$ & 0.312 & ND \\
\hline & 16 & $\mathrm{CH}_{3}$ & $\mathrm{H}$ & $\mathrm{F}$ & $\mathrm{CH}_{3}$ & $\mathrm{CH}_{3}$ & - & - & - & - & $41 \pm 5$ & $\leq 0.039$ & ND \\
\hline & 17 & $\mathrm{CH}_{3}$ & $\mathrm{OCH}_{3}$ & $\mathrm{~F}$ & $\mathrm{H}$ & $\mathrm{H}$ & - & - & - & - & $42 \pm 3$ & $\leq 0.039$ & $234 \pm 16$ \\
\hline \multirow[t]{3}{*}{ Group 4} & 18 & $\mathrm{CH}_{3}$ & $\mathrm{H}$ & $\mathrm{H}$ & $\mathrm{CH}_{3}$ & $\mathrm{CH}_{3}$ & - & - & - & - & $132 \pm 12$ & $\leq 0.039$ & ND \\
\hline & 19 & $\mathrm{CH}_{3}$ & \multicolumn{2}{|c|}{$3^{\prime}, 4^{\prime}$-dioxane } & $\mathrm{CH}_{3}$ & $\mathrm{CH}_{3}$ & - & - & - & - & $172 \pm 23$ & $\leq 0.039$ & ND \\
\hline & 20 & $\mathrm{CH}_{3}$ & \multicolumn{2}{|c|}{$3^{\prime}, 4^{\prime}$-dioxane } & $\mathrm{H}$ & $\mathrm{H}$ & - & - & - & - & $211 \pm 11$ & $\leq 0.039$ & $290 \pm 16$ \\
\hline \multirow[t]{6}{*}{ Group 5} & 21 & $\mathrm{~S}-\mathrm{CH}_{3}$ & $\mathrm{H}$ & \multicolumn{2}{|c|}{$3^{\prime}, 4^{\prime}$-dioxolane } & - & - & - & - & - & $38 \pm 5$ & $\leq 0.039$ & $191 \pm 12$ \\
\hline & 22 & $\mathrm{R}-\mathrm{CH}_{3}$ & $\mathrm{H}$ & \multicolumn{2}{|c|}{$3^{\prime}, 4^{\prime}$-dioxolane } & - & - & - & - & - & $74 \pm 4$ & $\leq 0.039$ & $85 \pm 10$ \\
\hline & 23 & $\mathrm{~S}-\mathrm{CH}_{3}$ & $\mathrm{H}$ & $\mathrm{H}$ & $\mathrm{OCH}_{3}$ & - & - & - & - & - & $207 \pm 12$ & $\leq 0.039$ & $68 \pm 7$ \\
\hline & 24 & $\mathrm{R}-\mathrm{CH}_{3}$ & $\mathrm{H}$ & $\mathrm{H}$ & $\mathrm{OCH}_{3}$ & - & - & - & - & - & $163 \pm 14$ & $\leq 0.039$ & $74 \pm 7$ \\
\hline & 25 & $\mathrm{~S}-\mathrm{CH}_{3}$ & $\mathrm{OCH}_{3}$ & $\mathrm{H}$ & $\mathrm{H}$ & - & - & - & - & - & $42 \pm 4$ & $\leq 0.039$ & $232 \pm 21$ \\
\hline & 26 & $\mathrm{R}-\mathrm{CH}_{3}$ & $\mathrm{OCH}_{3}$ & $\mathrm{H}$ & $\mathrm{H}$ & - & - & - & - & - & $31 \pm 4$ & $\leq 0.039$ & $144 \pm 17$ \\
\hline
\end{tabular}




\begin{tabular}{|c|c|c|c|c|c|c|c|c|c|c|c|c|c|}
\hline & 27 & $\mathrm{~S}-\mathrm{CH}_{3}$ & $\mathrm{H}$ & $\mathrm{OCH}_{3}$ & $\mathrm{H}$ & - & - & - & - & - & $33 \pm 5$ & $\leq 0.039$ & $366 \pm 23$ \\
\hline & 28 & $\mathrm{R}-\mathrm{CH}_{3}$ & $\mathrm{H}$ & $\mathrm{OCH}_{3}$ & $\mathrm{H}$ & - & - & - & - & - & $43 \pm 4$ & $\leq 0.039$ & $516 \pm 31$ \\
\hline & 29 & $\mathrm{CH}_{3}$ & $\mathrm{H}$ & $\mathrm{OCH}_{3}$ & $\mathrm{OCH}_{3}$ & - & - & - & - & - & $35 \pm 6$ & $\leq 0.039$ & $362 \pm 18$ \\
\hline & 30 & $\mathrm{R}-\mathrm{CH}_{3}$ & $\mathrm{H}$ & $\mathrm{OCH}_{3}$ & $\mathrm{OCH}_{3}$ & - & - & - & - & - & $95 \pm 5$ & $\leq 0.039$ & $206 \pm 21$ \\
\hline & 31 & $\mathrm{CH}_{3}$ & \multicolumn{2}{|c|}{$2^{\prime}, 3^{\prime}$-dioxolane } & $\mathrm{H}$ & - & - & - & - & - & $9 \pm 3$ & $\leq 0.039$ & $201 \pm 16$ \\
\hline & 32 & $\mathrm{CH}_{3}$ & $\mathrm{H}$ & $\mathrm{OH}$ & $\mathrm{OH}$ & - & - & - & - & - & $451 \pm 24$ & 0.312 & ND \\
\hline \multirow[t]{3}{*}{ Group 6} & 33 & $\mathrm{H}$ & - & - & - & - & - & - & $\mathrm{N}$ & - & $129 \pm 9$ & $\leq 0.039$ & $1133 \pm 175$ \\
\hline & 34 & $\mathrm{OH}$ & - & - & - & - & $N$ & - & $\mathrm{N}$ & - & $647 \pm 32$ & 2.5 & ND \\
\hline & 35 & $\mathrm{CH}_{3}$ & $\mathrm{CH}_{3}$ & - & - & - & $\mathrm{N}$ & $\mathrm{N}$ & - & - & $120 \pm 13$ & $\leq 0.039$ & ND \\
\hline
\end{tabular}

Interestingly, the presence of $3^{\prime}, 4^{\prime}$ dioxane (compounds 19 and 20) has minimal effect on the potency of PLAs $\left(\mathrm{IC}_{50}\right.$ values of 132 and $172 \mathrm{nM})$. By contrast, 3'4'-dioxalane substitution (compound $\mathbf{2 1}$ and 22) resulted in enhance inhibitory activity by as much as five-fold.

These observations prompted us to investigate different B-ring modifications in the contest of substituted and unsubstituted B-ring (group five). Moving the dioxolane substitution from $3^{\prime}, 4^{\prime}$ to $2^{\prime}, 3^{\prime}$ position yielded compound 31 , superior in both potency and selectivity, with $\mathrm{IC}_{50}$ value of $9 \mathrm{nM}$. These structural analysis highlights the importance of a simple change around the B-ring at 2', 3', and $4^{\prime}$ position on the potency and affinity of these compounds against SpDHFR.

Group six represent three compounds with para $\mathrm{C}$-ring and various nitrogen substitutions on $\mathrm{B}$ - and $\mathrm{C}$-rings. These compounds have moderate inhibitory activity with $\mathrm{IC}_{50}$ values above $100 \mathrm{nM}$. It is notable that replacement of the propargylic methyl with a hydroxyl moiety (compound 34 ) is not tolerated ( $\left(\mathrm{C}_{50}\right.$ value of $\sim 650 \mathrm{nM}$ ). Selectivity over the human form of DHFR, to ensure low toxicity, is an important parameter to consider. We have measured the inhibitory effect of select compounds against the human DHFR enzyme (HuDHFR) and reported it as $I C_{50}$ values (Table 1 ).

In summary, compounds lacking propargylic substitution (compounds 1 and 7) and/or those without bulky substitutions on the C-ring yielded more selective compounds. The main structural variations that drive the potency and selectivity of PLAs against SpDHFR appear to be the simplified propargyl, 2', and 3' substitution on the B-ring as well as meta-substitution on the $\mathrm{C}$-ring. 


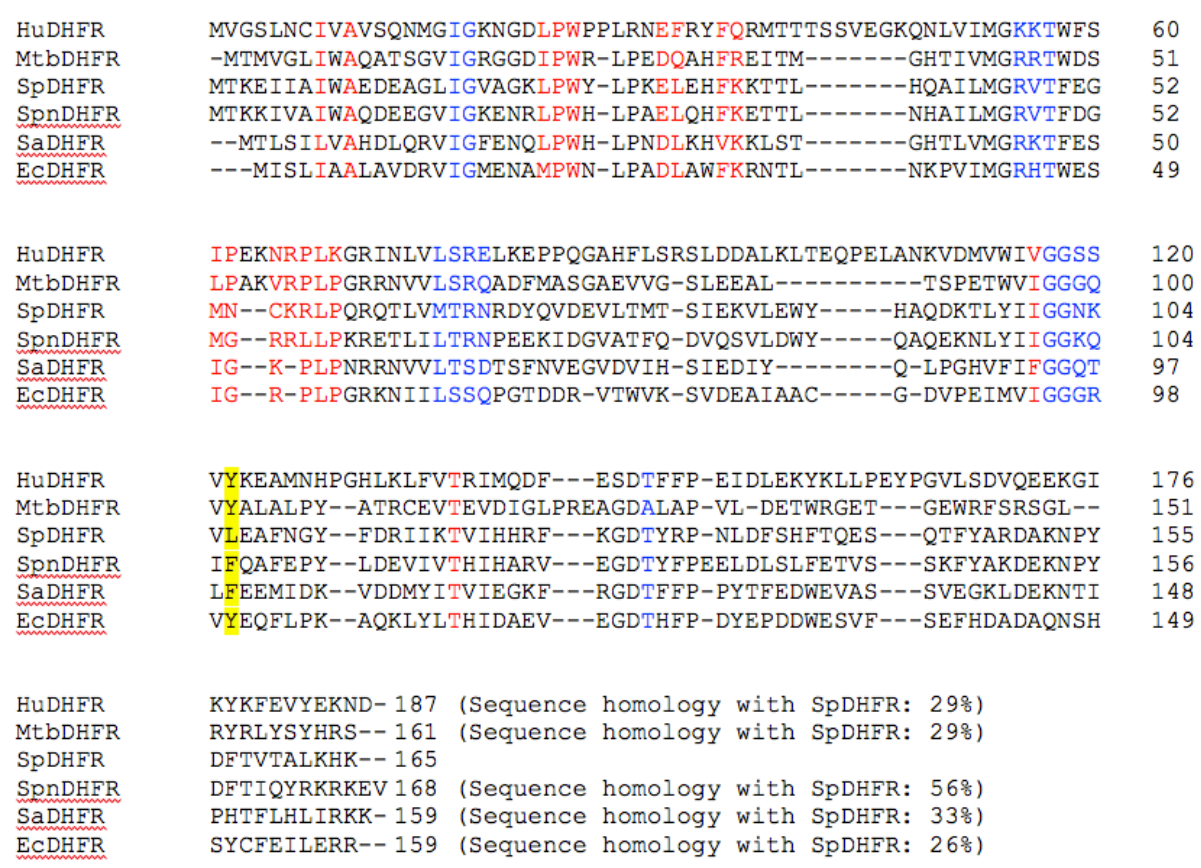

Figure 2. Sequence alignment of SpDHFR with other known DHFR enzymes. Folate binding site residues are shown in red. Cofactor binding site residues are shown in blue. Hu: Homo sapiens, Mtb: Mycobacterium tuberculosis, Spn: Streptococcus pneumoniae, Sa: Staphylococcus aureus, and Ec: Escherichia coli

Enzyme Structural Analysis. To investigate drug-target interactions, we have successfully crystalized SpDHFR in complex with compound 3 . The X-ray crystal structure of SpDHFR bound to cofactor $\mathrm{NADPH}$ and the ligand was determined at $2.2 \AA$ with the final $R$-factor of 0.19 and $R_{\text {free }}$ of 0.25 (Table S1). The crystal belongs to the orthorhombic space group P2 ${ }_{1}{ }_{1} 2_{1}$ with four molecules in the asymmetric unit. Despite low sequence homology with DHFR enzymes (Figure 2), SpDHFR structure exhibit the same general fold composed of a central $\beta$-sheet and four flanking $\alpha$-helices (Figure $3 \mathrm{~A}$ and $\mathrm{B}$ ). SpDHFR is composed of eight parallel $\beta$ strands $(\beta 1, \beta 2, \beta 3, \beta 4, \beta 5, \beta 6, \beta 7$, and $\beta 9)$, two anti-parallel $\beta$-strands ( $\beta 8$ and $\beta 10)$, and four $\alpha$-helices $(\alpha 1, \alpha 2, \alpha 3$, and $\alpha 4)$. Full density for both NADPH and compound 3 was also observed (Figure 4A).

NADPH binding site. The NADPH molecule is bound to SpDHFR in an extended conformation with the nicotinamide ring inserted into a cleft formed by $\beta 1, \beta 2$, and $\beta 8$-strands (Figures $3 A$ and $4 A$ ). NADPH is anchored into the cofactor binding pocket through extensive interactions with the active site residues (Figure 4B). The amide group of the nicotinamide ring forms three hydrogen bonds with the backbone of Ala10 and Ile17. The nicotinamide ribose contacts Val19, Gly21, and Lys22. The pyrophosphate moiety interacts extensively with the residues from $\alpha 2$ and $\alpha 4$ helices (Val48, Thr49, Asn103, and Lys104). The O2'-phosphate of adenosyl ribose forms 
A

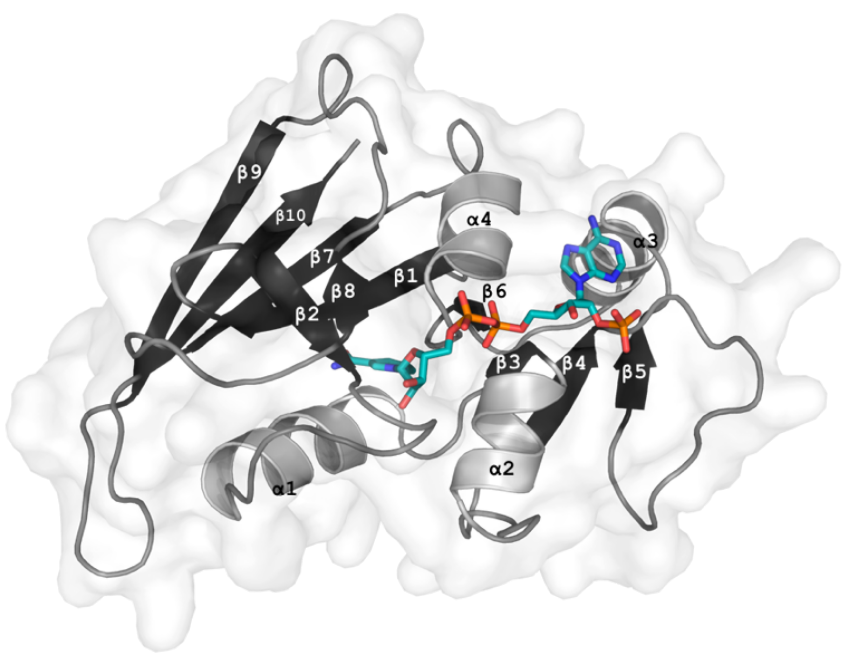

B
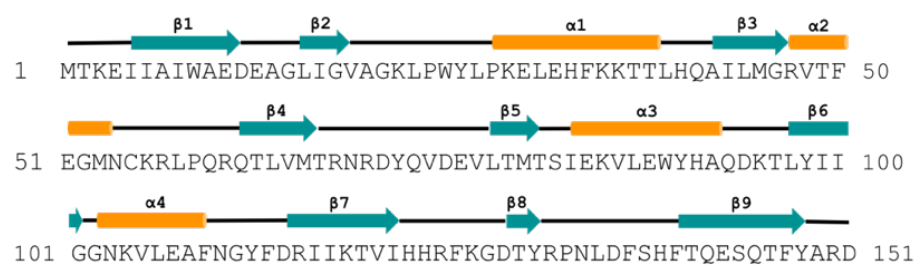

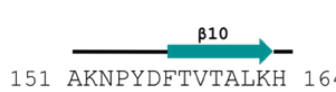

Figure 3. Structure of SpDHFR and assignment of secondary structures. A) Schematic ribbon diagram of the overall fold of SpDHFR. NADPH is shown using a stick model. B) Assignment of secondary structures for SpDHFR sequence.

four hydrogen bonds with Arg47, Thr67, and Arg68. The adenine group contacts the protein through interactions with Thr81 and Ser82 and stacking against Met66.

Folate binding site. The 2,4diaminopyrimidine ring of compound $\mathbf{3}$ is deeply positioned into the hydrophobic binding pocket and forms two hydrogen bonds with Glu30 and another hydrogen bond with the backbone carboxylate of lle8 (Figures 4A and 4C). Glu30 is highly conserved and critical for the catalytic activity of DHFR. In some species, this residue is replaced by Asp which provides similar interactions (Figure 2). There are also water-mediated interactions between the 2,4-diaminopyrimidine ring of compound $\mathbf{3}$ and the residues in the binding pocket and $\pi-\pi$ stacking with Phe34. This arrangement around the diaminopyrimidine ring is highly conserved among the known DHFR structures from various species. The biaryl moiety of compound $\mathbf{3}$ makes hydrophobic interactions with 11100 , Thr49, Phe50, Met53, and Leu58. The carboxylate of compound $\mathbf{3}$ has a weak electrostatic 

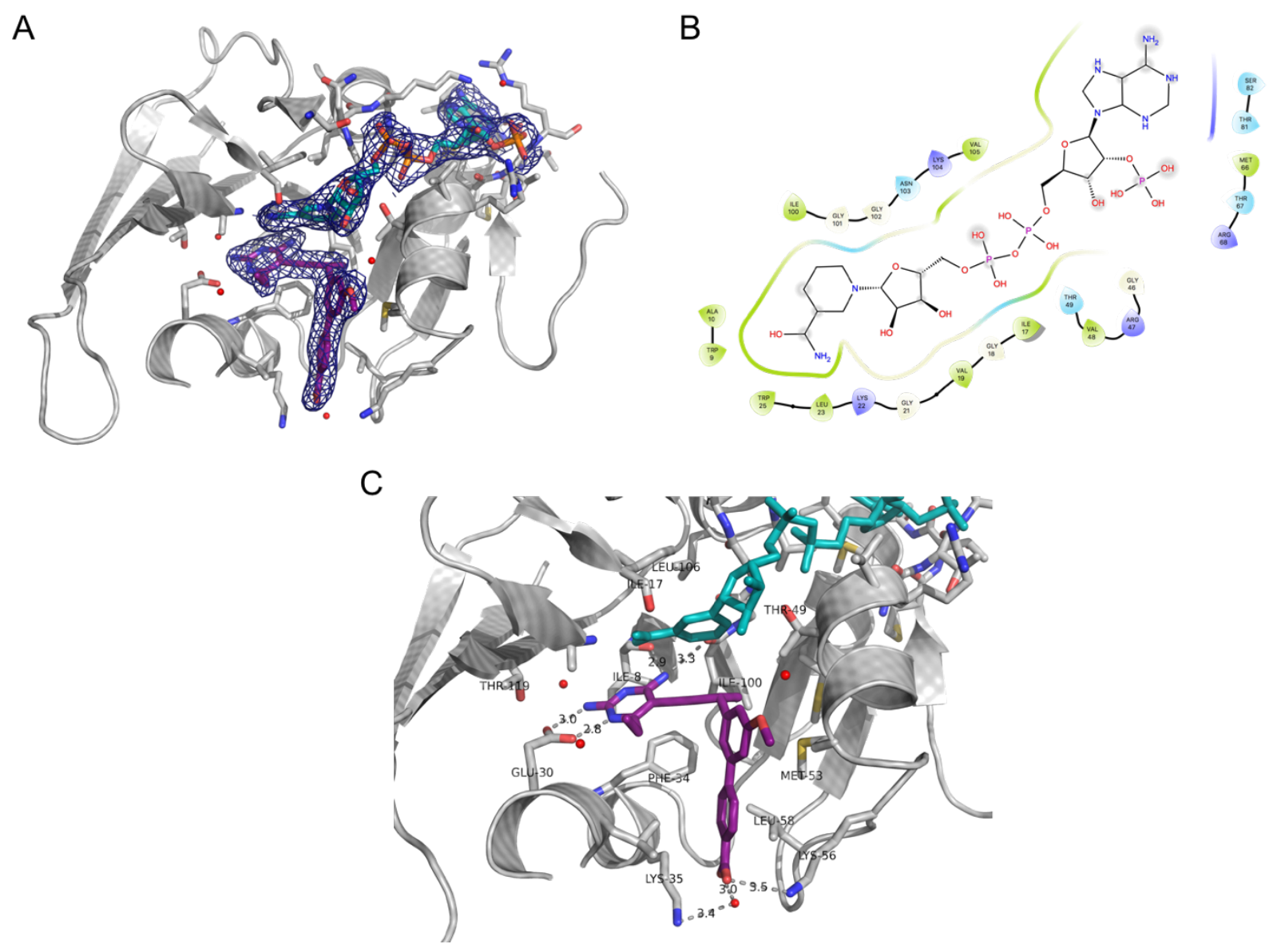

Figure 4. A) Structure of SpDHFR in complex with NADPH and compound 3, B) 2D diagram of NADPH interactions with the binding site residues, C) A detailed view of SpDHFR interactions with compound 3

interaction with Lys $56(3.5 \AA)$ and a watermediated interaction with Lys35.

\section{Comparison of DHFR enzymes from $S$.} pyogenes and $\mathbf{S}$. aureus. Despite low sequence homology (33\%), the general fold of the two protein is very similar. A direct comparison of the active site residues in SpDHFR structure with the previously reported structure of DHFR enzyme from $S$. aureus (PDB ID: 4Q67) ${ }^{21}$ revealed highly conserved binding pocket (Figure 5A) which should allow for the design of dual inhibitors of both enzymes.

Selectivity and Comparison with HuDHFR. SpDHFR contains 165 amino acids compared with 187 residues in the HuDHFR. Despite the larger size of the human protein and low sequence homology (29\%), the overall folding of the two proteins is very similar. By superimposing SpDHFR structure with human DHFR structure bound to the same 
ligand $^{22}$ (Figure 5B), it becomes evident that the interactions of the 2,4diaminopyrimidine ring that anchors compound $\mathbf{3}$ in the active site are almost identical.

Despite the similarities, there are several structural variations that can be exploited for design of selective inhibitors. For example, replacement of Phe31 in HuDHFR by corresponding residue Leu31 in SpDHFR provides greater van der Waals interactions in SpDHFR while the larger group likely contribute to destabilizing interactions in HuDHFR. Another notable difference is Pro61 in HuDHFR which corresponds to Asn54 in SpDHFR. Inhibitors with polar substitutions that can advantage from contacts with Asn54 may bind selectively to SpDHFR. An analog of compound $\mathbf{3}$ with a hydrogen bond donor on the C-ring or a hydrophilic group added to the B-ring may provide an excellent chemical space to explore. Still, a consideration should be given to the size, position, and character of these additional moieties as seen from our SAR analysis.
A

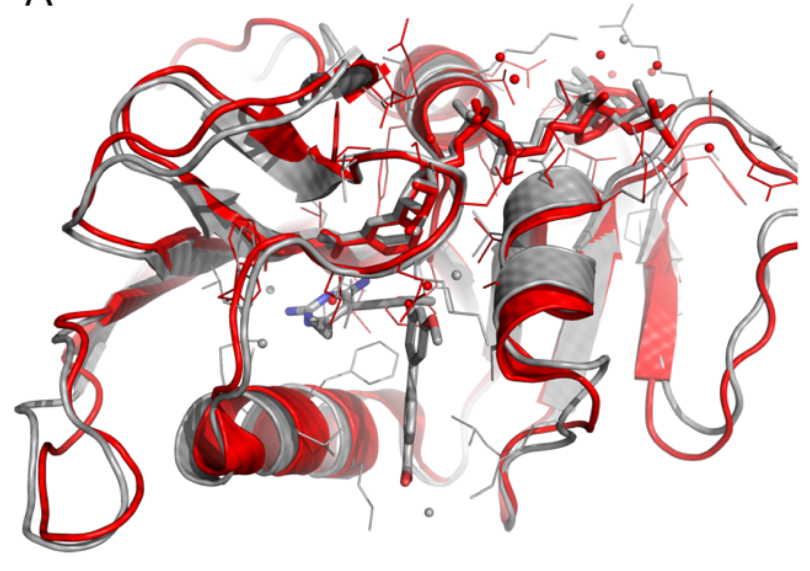

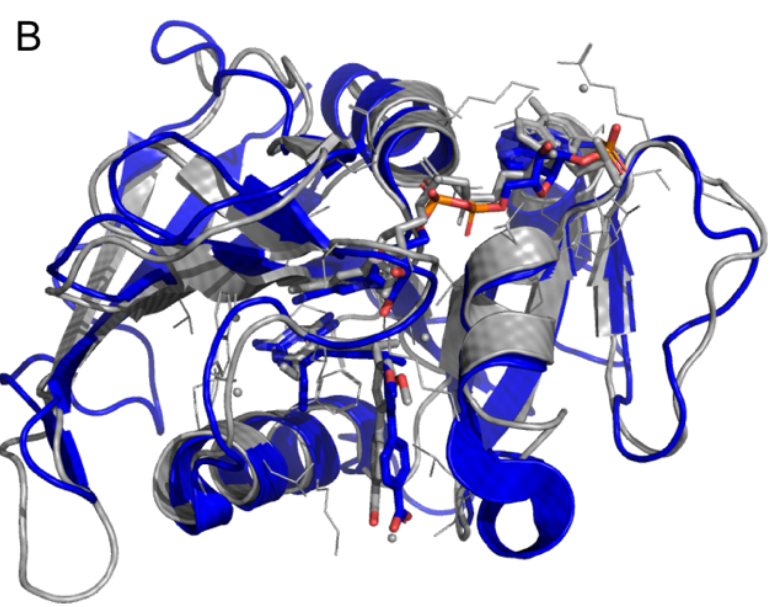

Figure 5. A) Superposition of SpDHFR (gray) and SaDHFR (red), B) Superposition of SpDHFR (grey) and HuDHFR (blue)

\section{CONCLUSION}

The results presented in this work, provide insights into the structure-based design of inhibitors of DHFR in S. pyogenes. DHFR inhibitors have been widely used as effective anticancer and antibacterial agents. ${ }^{15,23}$ However, resistance to TMP, one of the most effective DHFR inhibitors, has challenged the efficacy of this drug as an antibacterial agent. TMP, often in combination with SMX, is used for treatment of skin, urinary tract, and enteric infections caused by Gram-positive and 
Gram-negative bacteria. ${ }^{24-26}$ S. pyogenes causes million cases of human infections every year and its capacity to develop invasive infections emphasizes the need for global control of streptococcal infections. Common co-infection of $S$. pyogenes and MRSA and difficulties in distinguishing between the two, highlights the importance of developing therapeutics with activity against both pathogen and ideally TMPresistant isolates. Previously, we have reported a series of DHFR inhibitors with activity against TMP-sensitive and TMP- resistant MRSA isolates. ${ }^{17-20}$ Here, we have shown that these compounds maintain their inhibitory activity against DHFR enzyme from $S$. pyogenes and the growth of live bacteria. SAR analysis of the tested compounds along with determining the structure of SpDHFR in complex with one of the lead compounds provide key structural information required for optimization of dual inhibitors of both pathogen. 


\section{METHODS}

Antimicrobial agents. The synthesis and characterization of PLAs have been described in several publications. Trimethoprim (TMP) was purchased from Sigma Chemical Co., St. All the compounds were dissolved in 100\% dimethyl sulfoxide (DMSO) prior to use.

Bacterial isolate. S. pyogenes ATCC 19615 was purchased from the American Type Culture Collection (Manassas, VA). The organism was grown in Todd Hewitt broth.

In vitro susceptibility testing. The assay was performed in Isosensitest broth (Oxoid) supplemented with $5 \%$ defibrinated sheep blood (ThermoFisher). Minimum inhibitory concentrations (MIC) were determined by broth microdilution method based on CLSI guideline using a final inoculum of $5 \times 10^{5} \mathrm{CFU} / \mathrm{ml}$. The antimicrobial agents were prepared at $40 \mu \mathrm{g} / \mathrm{ml}$ and were dispensed using serial two-fold dilution. The MIC was defined as the lowest concentration of antimicrobial agent yielding no visible growth after monitoring cell turbidity following an incubation period of $24-36$ hours at $37^{\circ} \mathrm{C}$.

Transformation, expression, and purification of SpDHFR. Recombinant pET-24a(+) plasmid harboring the folA gene encoding SpDHFR was constructed by GenScript. BL21(DE3) competent E. Coli cells (New England BioLabs) were transformed with the recombinant plasmids. Transformed cells were grown in LB medium supplemented with $30 \mu \mathrm{g} / \mathrm{mL}$ kanamycin at $37^{\circ} \mathrm{C}$ until $\mathrm{OD}_{600}$ reached $0.6-0.7$. The cells were induced with 1 $\mathrm{mM}$ IPTG for 20 hours at $20^{\circ} \mathrm{C}$ and spun down at $8000 \mathrm{rpm}$ for 15 minutes. Each gram of wet cell pellet was resuspended in $5 \mathrm{ml}$ of lysis buffer $(25 \mathrm{mM}$ Tris pH 8.0, $0.4 \mathrm{M} \mathrm{KCl}$, $5 \mathrm{mM}$ imidazole, $5 \mathrm{mM} \mathrm{BME}, 5 \%$ glycerol, $200 \mu \mathrm{g} / \mathrm{ml}$ lysozyme, $1 \mathrm{mM}$ DNase I). The cell suspension was incubated for $30-60$ minutes at $4{ }^{\circ} \mathrm{C}$ with gentle rotation followed by sonication until a homogenous lysate was obtained. The lysate was centrifuged at 18,000 rpm for 30 minutes and supernatant was collected and filtered through $0.22 \mu \mathrm{m}$ filter. The SpDHFR construct did not contain histidine tag and were purified over methotrexate-agarose column pre-equilibrated with $4 \mathrm{CV}$ of equilibration buffer (20mM Tris- $\mathrm{HCl} \mathrm{pH}$ 7.5, $50 \mathrm{mM} \mathrm{KCl}, 2 \mathrm{mM}$ DTT, $0.1 \mathrm{mM}$ EDTA and 15\% glycerol). The column was washed with $3 \mathrm{CV}$ of wash buffer $(20 \mathrm{mM}$ Tris-HCl pH 7.5, $500 \mathrm{mM} \mathrm{KCl}, 2 \mathrm{mM}$ DTT, $0.1 \mathrm{mM}$ EDTA and 15\% glycerol). The protein was eluted with $3 \mathrm{CV}$ of elution buffer (equilibration buffer pH $8.5+2 \mathrm{mM}$ DHF). Fractions containing SpDHFR protein were collected, concentrated and loaded onto a Hi-Prep 26/60 Sephacryl s-200 HR prepacked gel filtration/size exclusion column pre-equilibrated with $1 \mathrm{CV}$ of final buffer $(25 \mathrm{mM}$ Tris $\mathrm{pH}$ 8.0, $50 \mathrm{mM} \mathrm{KCl}, 0.1 \mathrm{mM}$ EDTA, $2 \mathrm{mM}$ DTT and 15\% glycerol). The column was washed with another $1 \mathrm{CV}$ of final buffer and protein elution was monitored with AKTA UV/vis diode array spectrophotometer at $280 \mathrm{~nm}$. Fractions containing pure enzyme 
were pooled, concentrated at $10 \mathrm{mg} / \mathrm{ml}$ and flash frozen in liquid nitrogen and stored at $-80^{\circ} \mathrm{C}$.

Enzyme inhibition assay. The DHFR activity of SpDHFR was measured in $500 \mu$ l of assay buffer containing $20 \mathrm{mM}$ TES, $50 \mathrm{mM} \mathrm{KCl}, 0.5 \mathrm{mM}$ EDTA, $10 \mathrm{mM}$ 2-mercaptoethanol (BME) and $1 \mathrm{mg} / \mathrm{ml}$ bovine serum albumin (BSA) with various concentrations of NADPH and DHF ranging from 0 to $100 \mu \mathrm{M}$. Assay was started by adding DHF and monitoring $\mathrm{NADPH}$ oxidation at $340 \mathrm{~nm}$. All measurements were performed at room temperature and in triplicates. Initial velocity data were fitted with the Michaelis-Menten equation using Graphpad Prism 7.0 software. The DHFR activity inhibition assays and $I_{50}$ determination were performed in the same assay buffer with $100 \mu \mathrm{M}$ NADPH and 100 $\mu \mathrm{M}$ DHF. Inhibitors, dissolved in 100\% DMSO, were added to the mixture and incubated for 5 minutes before the addition of DHF. Average $I_{50}$ values and standard deviations were measured in triplicate.

Crystallization of SpDHFR. All the crystallization trials were performed by hanging drop vapor diffusion method and using EasyXtal 15-well plates (Qiagen). SpDHFR was mixed with $10 \mathrm{mM} \mathrm{NADPH}$ and $2 \mathrm{mM}$ ligand, incubated on ice for two hours and concentrated to $14 \mathrm{mg} / \mathrm{mL}$. $2 \mu$ of this solution was mixed with $2 \mu$ l of crystallization solution containing 50-150 mM sodium cacodylate $\mathrm{pH}$ 6-7, $200 \mathrm{mM}$ magnesium acetate, and 20-30\% of polyethylene glycol 3350. Small polygonal crystals grew within 2-3 weeks at $4{ }^{\circ} \mathrm{C}$. Crystals were flash frozen in the mother liquor supplemented with $20 \%$ glycerol.

Data collection and structure determination. X-ray data were collected at National Synchrotron Light Source II (NSLS II) at Brookhaven National Laboratory. Data were integrated using iMOSFLM and scaled and merged using AIMLESS from CCP4i2 suite. Molecular replacement was performed using Phaser and previously reported structure of DHFR from S. pneumoniae sharing $\sim 50 \%$ sequence identity with SpDHFR. The structure was refined using Coot and Phenix softwares.

\section{REFERENCES}

1. Barnett, T. C., Bowen, A. C. \& Carapetis, J. R. Epidemiology and Infection The fall and rise of Group A Streptococcus diseases. (2018). doi:10.1017/S0950268818002285

2. Carapetis, J. R., Steer, A. C., Mulholland, E. K. \& Weber, M. The global burden of group A streptococcal diseases. Lancet Infect. Dis. 5, 685-694 (2005).

3. Wong, S. S. \& Yuen, K.-Y. Streptococcus pyogenes and re-emergence of scarlet fever as a public health problem. (2012). doi:10.1038/emi.2012.9

4. PassÀli, D., lauriello, M., PassÀli, G. \& PassÀli, F. Group A Streptococcus and its antibiotic resistance Lo Strepotococco beta-emolitico di gruppo A e la sua resistenza alla terapia antibiotica.

5. Arvand, M., Hoeck, M., Hahn, H. \& Wagner, J. Antimicrobial resistance in Streptococcus pyogenes 
isolates in Berlin. J. Antimicrob. Chemother. 46, 621-624 (2000).

6. Passàli, D., Lauriello, M., Passàli, G. C., Passàli, F. M. \& Bellussi, L. Group A streptococcus and its antibiotic resistance. Acta Otorhinolaryngol. Ital. 27, 27-32 (2007).

7. Cattoir, V. Mechanisms of Antibiotic Resistance. Streptococcus pyogenes: Basic Biology to Clinical Manifestations (University of Oklahoma Health Sciences Center, 2016).

8. Reinert, R. R., Lütticken, R., Bryskier, A. \& Al-Lahham, A. Macrolide-resistant Streptococcus pneumoniae and Streptococcus pyogenes in the pediatric population in Germany during 20002001. Antimicrob. Agents Chemother. 47, 489-93 (2003).

9. Van Heirstraeten, L. et al. Antimicrobial drug use and macrolide-resistant Streptococcus pyogenes, Belgium. Emerg. Infect. Dis. 18, 1515-8 (2012).

10. Bingen, E. et al. Emergence of macrolide-resistant Streptococcus pyogenes strains in French children. Antimicrob. Agents Chemother. 48, 3559-62 (2004).

11. Silva-Costa, C., Friães, A., Ramirez, M. \& Melo-Cristino, J. Macrolide-resistant Streptococcus pyogenes: prevalence and treatment strategies. Expert Rev. Anti. Infect. Ther. 13, 615-628 (2015).

12. Bowen, A. C. et al. Is Streptococcus pyogenes resistant or susceptible to trimethoprimsulfamethoxazole? J. Clin. Microbiol. 50, 4067-72 (2012).

13. Bergmann, R., van der Linden, M., Chhatwal, G. S. \& Nitsche-Schmitz, D. P. Factors that cause trimethoprim resistance in Streptococcus pyogenes. Antimicrob. Agents Chemother. 58, 2281-8 (2014).

14. Bergmann, R., Sagar, V., Nitsche-Schmitz, D. P. \& Chhatwal, G. S. first detection of trimethoprim resistance determinant $\mathrm{dfr}$ in Streptococcus pyogenes clinical isolates in India. Antimicrob. Agents Chemother. 56, 5424-5 (2012).

15. Scocchera, E. \& Wright, D. L. in 1-27 (Springer, Berlin, Heidelberg, 2017). doi:10.1007/7355_2017_16

16. Kompis, I. M., Islam, K. \& Then, R. L. DNA and RNA synthesis: Antifolates. Chem. Rev. 105, 593620 (2005).

17. Scocchera, E. et al. Charged Nonclassical Antifolates with Activity Against Gram-Positive and GramNegative Pathogens. ACS Med. Chem. Lett. 7, 692-696 (2016).

18. Keshipeddy, S., Reeve, S. M., Anderson, A. C. \& Wright, D. L. Nonracemic Antifolates Stereoselectively Recruit Alternate Cofactors and Overcome Resistance in S. aureus. J. Am. Chem. Soc. 137, 8983-8990 (2015).

19. Reeve, S. M. et al. MRSA Isolates from United States Hospitals Carry dfrG and dfrK Resistance Genes and Succumb to Propargyl-Linked Antifolates. Cell Chem. Biol. 23, (2016).

20. Reeve, S. M. et al. Charged Propargyl-Linked Antifolates Reveal Mechanisms of Antifolate Resistance and Inhibit Trimethoprim-Resistant MRSA Strains Possessing Clinically Relevant Mutations. J. Med. Chem. 59, 6493-6500 (2016).

21. Reeve, S. M. et al. Protein design algorithms predict viable resistance to an experimental antifolate. Proc. Natl. Acad. Sci. U. S. A. 112, 749-54 (2015).

22. Hajian, B. et al. Drugging the Folate Pathway in Mycobacterium Tuberculosis: The Role of MultiTargeting Agents. (2018).

23. Visentin, M., Zhao, R. \& Goldman, I. D. The antifolates. Hematol. Oncol. Clin. North Am. 26, 62948, ix (2012).

24. Zhou, W., Scocchera, E. W., Wright, D. L. \& Anderson, A. C. Antifolates as effective antimicrobial agents: new generations of trimethoprim analogs. Medchemcomm 4, 908 (2013).

25. Adra, M. et al. Trimethoprim/sulfametrole: evaluation of the available clinical and pharmacokinetic/pharmacodynamic evidence. Ann. Pharmacother. 38, 1125-1133 (2011).

26. Adra, M. \& Lawrence, K. R. Trimethoprim/sulfamethoxazole for treatment of severe Staphylococcus 
bioRxiv preprint doi: https://doi.org/10.1101/504357; this version posted December 21,2018 . The copyright holder for this preprint (which was not certified by peer review) is the author/funder. All rights reserved. No reuse allowed without permission.

aureus infections. Ann. Pharmacother. 38, 338-341 (2004). 